\title{
Education in rural areas: benefits enjoyed by the children in the rural areas and the issues faced by them, solutions for the same and the teaching methodologies used in the class
}

\author{
Sai Shri Ramamurthy \\ Sree Venkateshwara Pre University College, Madiwala, Bengaluru
}

\begin{abstract}
This paper discusses about the benefits enjoyed by the children in the rural areas and the issues faced by them. The case study and action research was carried out by the coordinator of the PU college in a rural district near Bangalore. The strength of the classroom was 15 students, a hybrid group of students with different learning styles, slow learners and students with learning disabilities, moderate learners and fast learners. There is gender bias in some of the families against both the genders. The language skills seemed to be honed by the activities conducted like movie reviews and vocabulary building exercises. Before planning a lesson plan, the interests and hobbies of the students were studied and lesson plans were carefully devised considering the same. Bilingual method of teaching and one on one approach was also used. Different methods of teaching were adopted like inverted classroom technique, jigsaw method of teaching, structure and function approach, enquiry training model of teaching were used along with concept maps and mind maps. Students were divided into different groups and a subject teacher was assigned to each group thereby it is easier to give attention to a smaller group than the entire class and all the teachers and the students were engaged throughout the week after the regular classes to help the students learn. The students in the rural areas seem to better utilise the limited facilities available to them. The same methods were used to teach a set of students in Bangalore urban district, the class average was just $60 \%$ and in the rural district near Bangalore the class average was $86 \%$.
\end{abstract}

Keywords: Gender bias, language skills, fun activities, teaching methodologies. 


\section{Introduction}

The pedagogy adopted in teaching the students of the rural areas depends on the background the students come from, their age, the interests of the students, their learning styles and their hobbies. There are a number of benefits enjoyed by the children in the rural areas and a number of issues they face. This paper discusses about the case study and action research done by a coordinator of a PU college in a rural district near Bangalore. The strength of the class was 15 students and they were a hybrid group with fast learners, moderate learners, slow learners and students with learning disabilities.

\section{Interaction with parents}

Parents are one of the most importantly stake holders of education. The parents in the rural areas are a hybrid group with some people being educated and some are not but they do understand the importance of education and there is a sect that is neither educated nor do they understand the importance of education. To the parents who are educated, and with respect to the parents who know the importance of education, the issues faced are that the students are being pressurized by the parents to study and not given enough time to relax thereby getting the students frustrated. The set of parents who don't know the importance of education, there are a lot of issues faced by the students at home.

\section{(I) Gender bias}

Gender bias happens both ways. With respect to boys, when the performance in the tests goes below average or when a boy fails in the tests, instead of Encouraging him, there are families that say that a man can get another job and education isn't mandatory for men, leave alone the collegiate education, there are families that feel a blue collared job can be sufficient to feed and not even secondary education is mandatory for men. On the contrary, there are families which feel that a girl is anyway going to get married off to another family and education isn't important for a girl.

There are also families that pressurise male students and single girl child and families with all girl children to perform well sometimes forced to take groups which they aren't even interested in. 
(II) Parents not turning up for parent teacher meetings is another issue. And even if they turn up, there are parents who don't give a ear to what the teacher or the Principal has to say and moreover there are parents who show an authoritarian attitude towards the teachers and also the Principal who feel the responsibility of educating the children lies with the teachers alone.

There are parents who cooperate with the school authorities to help the children get all round education, by allowing students to make decisions to make choices about their career, by encouraging them to do better in tests and also help them to hone their skills in co-curricular activities as well.

\section{Language skills}

Most of the students study in English medium schools but then their language skills are not upto the mark when compared to most of the students in the urban areas.

There are ways to hone their language skills

\section{Reading Poetry}

When Poetry is being taught, students are allowed to read the poems aloud and students are also encouraged to write their own poems in the native language and then they are translated to English by the students, as the students read out their translated version, grammatical errors are corrected if there's any and they are also given help with the pronunciation.

\section{Reading newspapers}

Reading newspapers are being made mandatory and students would share the responsibility of reading out the day's news to the class.

\section{Vocabulary building exercises}

A couple of words are given to the students and the students are asked to find out the meanings and also to write down sentences of their own using the same. 


\section{$2^{\text {nd }}$ International Conference on Modern Research in EDUCATION, TEACHING AND LEARNING}

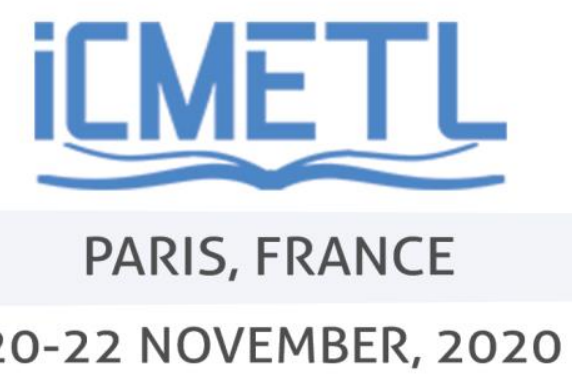

\section{Fun activities}

Fun activities always aid in the process of learning. There were different types of fun activities planned by the teacher, students were divided into groups and each group was given a product to advertise. The rule was simple the jingles used and the entire conversation must be in English. The students were asked to discuss about their favorite cartoon characters, movies and their favorite food items in English.

Different topics were written in chits and students were called and asked to pick chits, they were given a couple of minutes to frame sentences and they were asked to talk about the same in front of the class. Students were also prescribed Intermediate English Grammar book by Raymond Murphy and Norman Lewis's Word Power Made Easy.

Students in the rural areas seem to have clear career options as they either own or their parents work in farmlands or own cattle, so there are many takers for Dairy technology, agricultural sciences and agricultural engineering courses. They have a passion towards agricultural sciences and some of the students are so passionate about taking up research in the same.

The students in the rural areas have lesser possible options for getting distracted and the things that distract them are equally healthy as an inter Generic friendship with a cow or a buffalo and sports.

Poems were written for the students to motivate them. Bilingual method of teaching was used. One on one approach for the slow learners and the gifted students proved to be effective.

There were a variety of methods and techniques used to teach and help the students learn, jigsaw method of teaching, enquiry training model, inverted classroom technique, structure and function approach and dumb charades were conducted once in a week to revise the concepts taught and quizzes were conducted wherein the students were divided into groups and the questions were framed by the students for the opposite teams which facilitated deeper understanding of the subject being taught or rather facilitated to learn.

Students were also taught to construct mind maps and concept maps which helped the students, especially the students with learning disabilities learn better. 
As the students don't have the same resources as the students in the urban areas, students were divided into different groups and a subject teacher was assigned to each group thereby it is easier to give attention to a smaller group than the entire class and all the teachers and the students were engaged throughout the week after the regular classes to help the students learn.

\section{Conclusion and findings}

When the students were given individual attention, when lesson plans were made according to their interests the students in the rural areas scored much better. The same methods were used to teach a set of students in Bangalore urban district, the class average was just $60 \%$ and in the rural district near Bangalore the class average was $86 \%$.

\section{References:}

1)Chukwu, J., \& Arokoyu, A. (2019). Effects of Jigsaw-Puzzle Instructional Strategy on Secondary School Students' Performance on Growth as a Concept in Biology in Abia State. Advances in Research, 20(1), 1-6. https://doi.org/10.9734/air/2019/v20i130148

2)PAPALEXIOU, A. G., PAPADAKIS, S., MANOUSOU, E., \&amp; GEORGIADU, I. (2017). IMPLEMENTING A FLIPPED CLASSROOM: A CASE STUDY OF BIOLOGY TEACHING IN A GREEK HIGH SCHOOL (Vol. 18). Turkish Online Journal of Distance Education-TOJDE. doi:ISSN 1302-6488

3) Siddiqui, M. H., Dr. (2013). Biological Science Inquiry Model: A Process of Study (Vol. 2, Ser. 4). Aligarh, Uttar Pradesh: PARIPEX - INDIAN JOURNAL OF RESEARCH. doi:ISSN 2250-1991

4) Christine Chin, 1997, Promoting higher cognitive learning in science through a problemsolving approach, National Institute of Education, Singapore.

5)Blosser, P. E. (1988). Teaching problem solving-Secondary school science.ERIC/SMEAC Science Education Digest, 2. (ERIC Document Reproduction Service No. ED 309 049).

6) Nnorom, N. R., Dr. (2019). Effect of Problem Based-Solving Technique on Secondary School Students Achievement in Biology. International Journal of Scientific \&amp; Engineering Research, 10(3). doi:ISSN 2229-5518. 


\section{PARIS, FRANCE}

20-22 NOVEMBER, 2020

7) Brahmapurkar K. P. (2017). Gender equality in India hit by illiteracy, child marriages and violence: a hurdle for sustainable development. The Pan African medical journal, 28, 178. https://doi.org/10.11604/pamj.2017.28.178.13993

8) Dunn, D. Gender inequality in education and employment in the scheduled castes and tribes of India. Popul Res Policy Rev 12, 53-70 (1993). https://doi.org/10.1007/BF01074509

9) Srivastava, G. (n.d.). Gender Concerns in Education. RMSA Module. Retrieved October 17, 2020. 